Article

\title{
How a Tourism City Responds to COVID-19: A CEE Perspective (Kraków Case Study)
}

\author{
Joanna Kowalczyk-Anioł ${ }^{1,2}$, Marek Grochowicz ${ }^{3,4}$ and Robert Pawlusiński ${ }^{4, *}$ (1) \\ 1 Institute of Urban Geography, Tourism Studies and Geoinformation, Faculty of Geographical Sciences, \\ University of Lodz, 90-136 Łódź, Poland; joanna.kowalczyk@geo.uni.lodz.pl \\ 2 CiTUR Center for Tourism Research, Development and Innovation, Polytechnic of Leiria, \\ 2411-901 Leiria, Portugal \\ 3 Institute of Urban and Regional Development, 03-728 Warszawa, Poland; mgrochowicz@irm.krakow.pl \\ 4 Institute of Geography and Spatial Management, Faculty of Geography and Geology, Jagiellonian University, \\ 31-007 Kraków, Poland \\ * Correspondence: robert.pawlusinski@uj.edu.pl
}

Citation: Kowalczyk-Anioł, J.; Grochowicz, M.; Pawlusiński, R. How a Tourism City Responds to COVID-19: A CEE Perspective (Kraków Case Study). Sustainability 2021, 13, 7914. https://doi.org/ $10.3390 /$ su13147914

Academic Editors: Marek Nowacki and Alan Fyall

Received: 30 April 2021

Accepted: 9 July 2021

Published: 15 July 2021

Publisher's Note: MDPI stays neutral with regard to jurisdictional claims in published maps and institutional affiliations.

Copyright: (C) 2021 by the authors. Licensee MDPI, Basel, Switzerland. This article is an open access article distributed under the terms and conditions of the Creative Commons Attribution (CC BY) license (https:/ / creativecommons.org/licenses/by/ $4.0 /)$.

\begin{abstract}
Academic papers on the COVID-19 pandemic and tourism adopt the perspective of strengthening tourism resilience or recognize the ongoing crisis as an opportunity for reflection and the need to redefine tourism development strategies. This article examines these issues using the example of Kraków, a tourism city that, on the eve of the pandemic outbreak, was experiencing symptoms of overtourism. Using a case study approach, the authors illustrate the strategies applied at the city level, as well as the range of measures and actions used to support the tourism industry during the full pandemic year. The Kraków case shows that the pandemic time can be used to reorganize relations between local tourism stakeholders and to create a new formula for a tourism city in the so-called 'new normal'. In addition, the exploratory case study allows for the formulation of research problems for further work on tourism cities responses to COVID-19. This can focus on a revision of the tourist offer and profile; the role of culture and the accompanying technologyfacilitated innovations; the continuation of 'being-a-tourist-in-your-own-city', as promoted in the pandemic; tourists' reactions to introduced changes; and shaping (new) relations between tourism stakeholders in the (post)pandemic city.
\end{abstract}

Keywords: COVID-19; urban tourism; heritage city; tourism recovery; Kraków; Poland (CEE)

\section{Introduction}

A rich body of literature shows that tourism and hospitality are sensitive to crises [1-4]. While natural and human-made disasters are quite common in tourism [5] and many destinations have developed successful resilience and crisis mitigation strategies [6]). As Collins-Kreiner and Ram [7] indicate, the COVID-19 tourism crisis is different in many respects. First of all, it has a global reach. Secondly, the economic collapse caused by COVID19 has been more dramatic than in previously observed crises [8]. Thirdly, the COVID19 pandemic has cascaded [9], causing damage throughout the tourism and hospitality sector [10]. According to many academics [11], the ongoing pandemic has the potential to cause fundamental modifications in many tourism segments. In many destinations, COVID-19 has become a 'crisis embedded in another crisis', especially in places already suffering on the socio-economic front [12].

Urban tourism destinations, especially those most dependent on international markets, are particularly sensitive to the COVID-19 crisis. It was initially expected that domestic tourism would recover in 2021 and the renewal of international tourism would probably take two years or more [13]. The first year of the pandemic showed that the situation in tourism cities and the entire tourism sector is very difficult, and that the circumstances dictated by the pandemic are varied. The revised forecasts prepared by experts suggest 
that the tourism industry's recovery will be slow, as new COVID-19 variants are causing governments to continue using travel bans to thwart the virus spread [8].

The COVID-19 crisis has changed tourism and the tourism industry as well as tourism research [14]. A review of the current literature on the impact of the pandemic on tourism shows that opinion papers, conceptual papers and research notes dominate, while there are only a few empirical studies $[7,15,16]$. Most of the papers published investigate the impacts of COVID-19 on tourism on a global scale $[16,17]$. Among the different research approaches, the most common are those reporting the impacts of COVID-19 and discussing the resumption of activities during and after the pandemic [17]. Developing simulations, scenario modeling and estimating the consequences of COVID-19 in terms of economic decline appeared less frequently.

Interestingly, Szarma, Thomas and Paul [15] show that clusters of keywords connected to tourism and the COVID-19 pandemic in the literature consist of two major themes, namely broadly defined resilience and transformation to a new global economic order. The authors of the second thematic group consider this crisis as an opportunity to reflect on existing mass tourism policies and to redefine tourism development pathways [5]. They call for transformations in (global) tourism policies in order to make them more consistent with sustainable development goals.

It is symptomatic that there is research on tourism and dealing with COVID-19 at the national level [7] while studies on tourism cities are sporadic and focus mainly on those in Asia [10,18-20]. The only published research that relates directly to the actions undertaken by tourism cities is the 'Report on Recovery and Development of World Tourism amid COVID-19' [21], prepared by the World Tourism Cities Federation (WTCF) together with experts from the University of Nevada, the University of Las Vegas and the University of North Texas. Nevertheless, there is a need for empirical papers, especially case studies (first exploratory and then explanatory [22]), which will allow for an in-depth appreciation and understanding of this new (urban) issue, as well as for the formulation of new research questions appropriate to the new situation and the challenges facing tourism cities.

Taking into account that the reactions and responses of tourism cities to COVID-19 are a phenomenon that has been poorly identified and described so far, the key research question formulated in this paper is: how does a tourism city respond to the COVID-19 tourism crisis? In this article, a single exploratory case study focuses on Kraków, which, after the political transformation in the 1990s, had become one of the most popular tourism cities in Central and Eastern Europe (CEE) before the outbreak of the pandemic [23,24]. The main aim of this article is to present the tourism city's response to the challenges of the COVID-19 crisis related to the tourism sector, focusing on Kraków's measures during the first year of struggle with the pandemic.

\section{Methodological Framework}

As a consequence of stating the research question, this article has a qualitative research character [25]. It uses a case study approach which is particularly useful to 'investigate contemporary phenomena within its real-life context' [22] as well as opening the prospect of a continuous development of knowledge in this area. The methodological framework of the research is presented in Figure 1.

Thomas [26] suggests that 'analytical eclecticism' is a defining factor for a case study, and this one involves multiple sources of information, including critical literature studies, thematic report analysis, official documents and local press articles. However, due to the completely new and dynamic nature of the situation and the accompanying phenomena, these sources of information, usually readily available, are still very limited. 


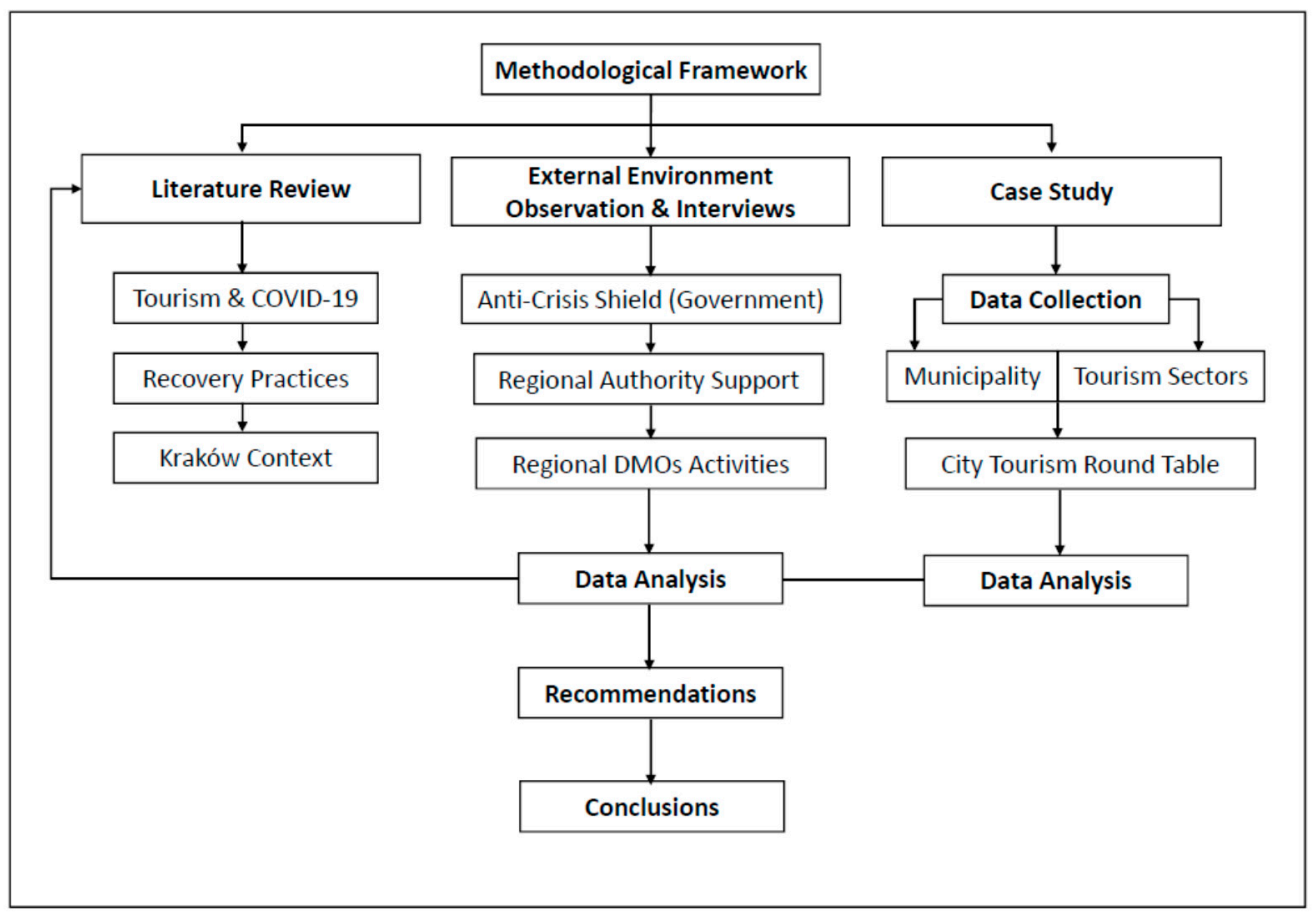

Figure 1. Methodological framework. Source: authors based on [27]. The paper is on CC-BY licence.

In such a situation, participant observation was particularly valuable for the Kraków case study. This was related to the authors' active participation in thematic discussions concerning a redefinition of the direction of Kraków's tourism policy and the actions aimed at mitigating the negative effects of the pandemic. As a consequence, interviews with local city authorities and local tourism stakeholders, the analysis of working documents, along with an insight into the initiatives and actions were indirectly used to shape the narrative in the case study of Kraków.

Yin [22] suggests that a case study should be presented within its context, while Stake [28] indicates that a wider phenomenon may be manifested by a given case. Such a case study is classified by Stake [28] as instrumental and uses a particular case to gain a broader appreciation of a phenomenon.

In this paper, the actions of tourism cities towards COVID-19 aimed at saving and reviving the tourism sector constitute an important thematic context for the Kraków case study. Treating the aforementioned WTCF report as the only compendium available in this respect so far, an additional objective of the article is to present the measures adopted by tourism cities to protect the tourism sector, as well as their strategies 'to speed up the recovery of the tourism and hospitality industry' [21].

\section{Coping with COVID-19: Tourism Response and Recovery at the Urban Destination Level}

In September 2020, the WTCF held a World Conference on Tourism Cooperation and Development themed 'Rebuilding World Tourism for Prosperity'. At the conference, the 'Report on Recovery and Development of World Tourism amid COVID-19' which presents three levels of action taken against COVID-19 was presented. The first focuses on the observed actions at the national level, the second (the most important for this article) at the city level, and the third at the level of entities in the tourism industry (airlines, hotels, tourist attractions) [21].

The report explored the situation and actions in six purposely selected world tourism cities, namely Barcelona, Beijing, Buenos Aires, Casablanca, Los Angeles and Samarkand. The information collected in the report and its recommendations can be treated as a matrix 
of proposed solutions. In the following parts of the article, each of the recommendation areas is briefly addressed.

The 'Report on Recovery and Development of World Tourism amid COVID-19' proposed coping strategies consisting of two stages: (I) crisis response and (II) tourism industry recovery (Figure 2).

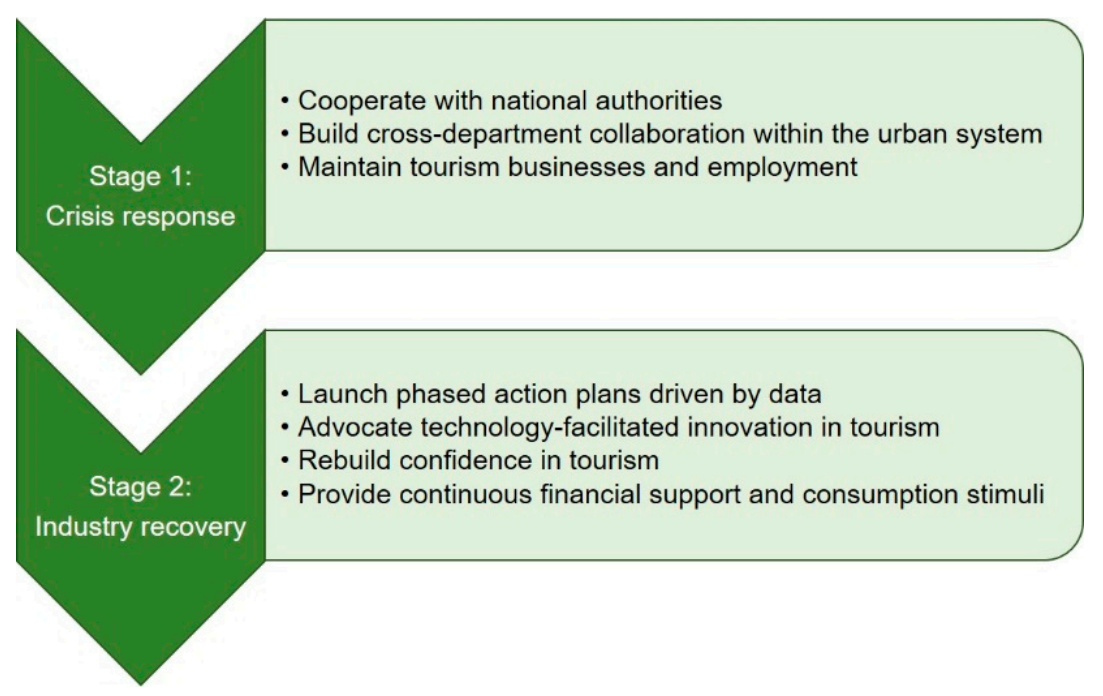

Figure 2. Coping with COVID-19 at the city level: tourism response and recovery strategies. Source: authors based on WTCF [21].

\subsection{COVID-19 Crisis Response Stage}

In the Covid-19 crisis' response stage (Figure 2), three primary measures for protecting tourism and hospitality are distinguished, namely (1) cooperation with national authorities, (2) building cross-departmental collaboration within the urban system, (3) maintaining tourism businesses and employment [21].

\subsubsection{Cooperation with National Authorities}

Cities, especially large ones, play an important role as nodes in economic, political, administrative and communication networks. In the current situation, the role of the city as a public management node is especially important, and as such it efficiently organizes, coordinates and implements adaptive measures to face the COVID-19 pandemic outbreak. Tourism cities located in various political systems follow the instructions and implement the restrictions adopted by national authorities such as social distancing, mask-wearing, swift tracing of confirmed cases (e.g., DetecTAr in Buenos Aires, LocalHealth in Beijing), testing (checkpoint allocation), as well as raising public awareness by introducing changes in the organization of public space, e.g., the establishment of one-way mobility circulation, the temporary closure of secondary public places, and a visible and intensified sanitation of public spaces [29].

Many of the solutions for facing the outbreak in cities are technology-based, and corona applications available for smartphones are especially popular [30]. Some of the COVID-19 technologies are viewed, discussed and socially rejected as controversial [14]. However, some of the new technological tools for responding to COVID-19 have a chance to take root in urban data management, since they can support an improvement in the quality of public life in post-COVID-19 cities [31].

\subsubsection{Building Cross-Departmental Collaborations within an Urban System}

COVID-19 has given rise to a new model of tourism governance [32]. Vargas [32] especially highlights new roles for destination management organizations (DMOs) for a new era. He suggests the need for the evolution of DMOs toward the performance of three 
different roles, namely as the orchestrator of various stakeholders in the destination; as the facilitator of opportunities for its members; and as the intelligence promoter and strategic mind. In the context of these challenges, the importance of human resource management as a factor determining the organizational effectiveness of DMOs is undoubtedly growing [33]. At the same time, the ability of a DMO and administrative offices to proactively respond to a pandemic such as COVID-19 is increasingly associated with using Big Data in decisionmaking [34]. Pasquinelli et al. [35] emphasize that, especially in the case of previously 'overtouristified' cities, social media play an important role in COVID-19 tourism policy and destination branding.

The WTCF report shows that such cross-departmental collaboration can vary both in function and in the focal points of the actions they undertake. For example, the Coordination Center for the Economic Response (CECORE) established in Barcelona has been structured into eight sectoral task forces. One of them is responsible for the incorporation of partnerships (integrating all social and economic stakeholders), monitoring economic changes in tourism, and guiding local policy-making accordingly. In Beijing, eight working groups are tasked with coordinating administrative resources, collecting feedback and proposing plans to the municipality, while providing concrete support to the tourism and culture sectors [21].

\subsubsection{Maintaining Tourism Businesses and Employment}

Tourism cities make financial support plans available to local tourism companies, including hotels, restaurants and entertainment, whenever possible. These packages are designed to provide immediate and direct financial support or a cost deduction to relieve operational pressures and ease their urgent financial problems. Such initiatives by cities include emergency financing (Los Angeles, Beijing), tax breaks or exemptions (Barcelona, Beijing), extended deadlines and a prolonged exemption date for delay payment penalties (Beijing) [21].

Authorities create opportunities to encourage temporary functional shifts and selfrescue initiatives to supplement income losses [21]. Especially in the emergency phase, many hotels actively participated in the anti-pandemic battle to accommodate medical staff, infected patients with mild symptoms, quarantined citizens (e.g., Beijing) and stranded travelers [30]. In many cities tourism businesses were providing meals for medical personnel, and (in some cities) vulnerable people (Buenos Aires).

\subsection{Stage Two: Tourism Industry Recovery}

In stage two, defined by the WTCF report as 'tourism industry recovery', four strategies are recommended as solutions to speed up the recovery of the tourism and hospitality industry for cities [21]. Suggested solutions are (1) launch of a data-driven phase model of action; (2) advocating technology-facilitated innovation in tourism; (3) rebuilding confidence in tourism; (4) providing continuous financial support and consumption stimuli (Figure 2).

\subsubsection{Launch of a Data-Driven Phase Model of Action}

Tourism cities face a dilemma and try to find a balance between a lockdown resulting in economic destruction and a reopening which increases the risk of accelerating virus spread. When virus curves are flattened, cities launch a phased model of action for a gradual restart for economies and businesses [10]. Based on the data and the evaluation of infection risks, the program usually has four phases: stay-at-home, low risk, high risk, and normal. Each stage may last at least three weeks [21]. Municipalities and relevant public services should closely monitor changes in local infection cases and, based on this information, decide whether to go to the next phase or go back to the previous one.

The local (municipal) government also undertakes initiatives to gradually resume tourist activities. Various action scenarios are observed. Some cities use a phased model of opening, from local consumption to regional and national markets and to international 
ones (e.g., Spanish cities). Other attempts to revive cities have been made through various, especially online-based, innovations. An interesting example in this regard is Beijing, where 'the municipality and tourism authorities started from online entertainment (virtual museums, exhibitions and talk shows), then gradually moved to offline activities with limited crowd gathering aligned with safety protocols, and finally achieved the goal of rebuilding business confidence and upgrading the tourism industry' [21].

\subsubsection{Advocating Technology-Facilitated Innovation in Tourism}

The significant impact of information and communication technologies (ICTs) on tourism, already observed before the COVID-19 pandemic [36,37], has significantly accelerated [38]. The battle against the COVID-19 pandemic has driven the massive and rapid deployment of emerging technologies (e.g., artificial intelligence, robots) [39]. On the one hand, the rapid emergence of technological solutions for tourism brought challenges. Nevertheless, opportunities became apparent especially during the total lockdown phase $[40,41]$. In many cities, authorities and multi-stakeholders overcame the travel restrictions and lockdown by starting to use technology-facilitated innovations to attract tourists and entertain them. This is an increasingly popular tool for keeping the connections between tourists and destinations.

Such technology-facilitated innovations in tourism cities include augmented reality, which has facilitated virtual tours; live-streaming broadcasting, which has gained the attention of tourism cities as a new channel for creating and circulating travel experiences and promoting destinations; free culture remote learning; and big data in contact tracing [21]. As previously noted, the COVID-19 pandemic has accelerated and strengthened the application of next-generation ICT solutions in tourism. Technology enables tourism cities to be connected with guests, stakeholders, partners, experts and others.

\subsubsection{Rebuilding Confidence in Tourism}

Safety in travel destinations is a prerequisite for rebuilding tourists' confidence [42]. Thus, safety and health protocols in destinations are crucial [21]. Tourism cities adopt the sanitary measures recommended by tourism industry organizations (e.g., World Travel Organization (WTO), World Travel \& Tourism Council (WTTC), as well as national and local disease-control centers [43]). For European destinations, some suggestions on how to gradually lift travel restrictions and allow tourism businesses to reopen are included in the European Commission package of guidelines and recommendations [44].

In addition to activities in public spaces and places, local businesses are shown how to follow recommended safety protocols. Self-action is also visible, especially in hotel brands, by introducing special cleaning standards and anti-pandemic cleaning measures to restore customers' confidence [45]. Some cities, such as Buenos Aires, have obtained Safe Travel Seals, developed by WTTC to strengthen tourists' confidence [46].

Rebuilding business confidence is an equally important issue. Tourism cities undertake various activities to this end. Various webinars and training sessions are organized for local tourism, cultural, hospitality and leisure stakeholders in order to prepare them for coping.

\subsubsection{Providing Continuous Financial Support and Consumption Stimuli}

At the response stage, cities try to stimulate consumption in the tourism sector with separate funding. Some have measures of direct subsidy to residents (e.g., Los Angeles), or awarding funds to businesses based on employment size (e.g., Barcelona) or project size (e.g., Casablanca).

Parallel to subsides and support for businesses, some cities have introduced new mechanisms by distributing coupons directly to consumers to stimulate demand. Usually providing $30-50 \%$ discounts, their goal is to encourage residents to shop locally. For example in Beijing, 'for every 100 RMB spent at local restaurants, cafes, hotels and other hospitality businesses, consumers will receive a 30 RMB reduction' [21]. 


\section{Case Study: Kraków}

Kraków, the second largest city in Poland (inhabited by 781,000 residents in 2020 [47]) is located in the south of the country (Figure 3). As the former capital (1038-1609), Kraków is an historic European center where heritage has significantly determined its present position [48].

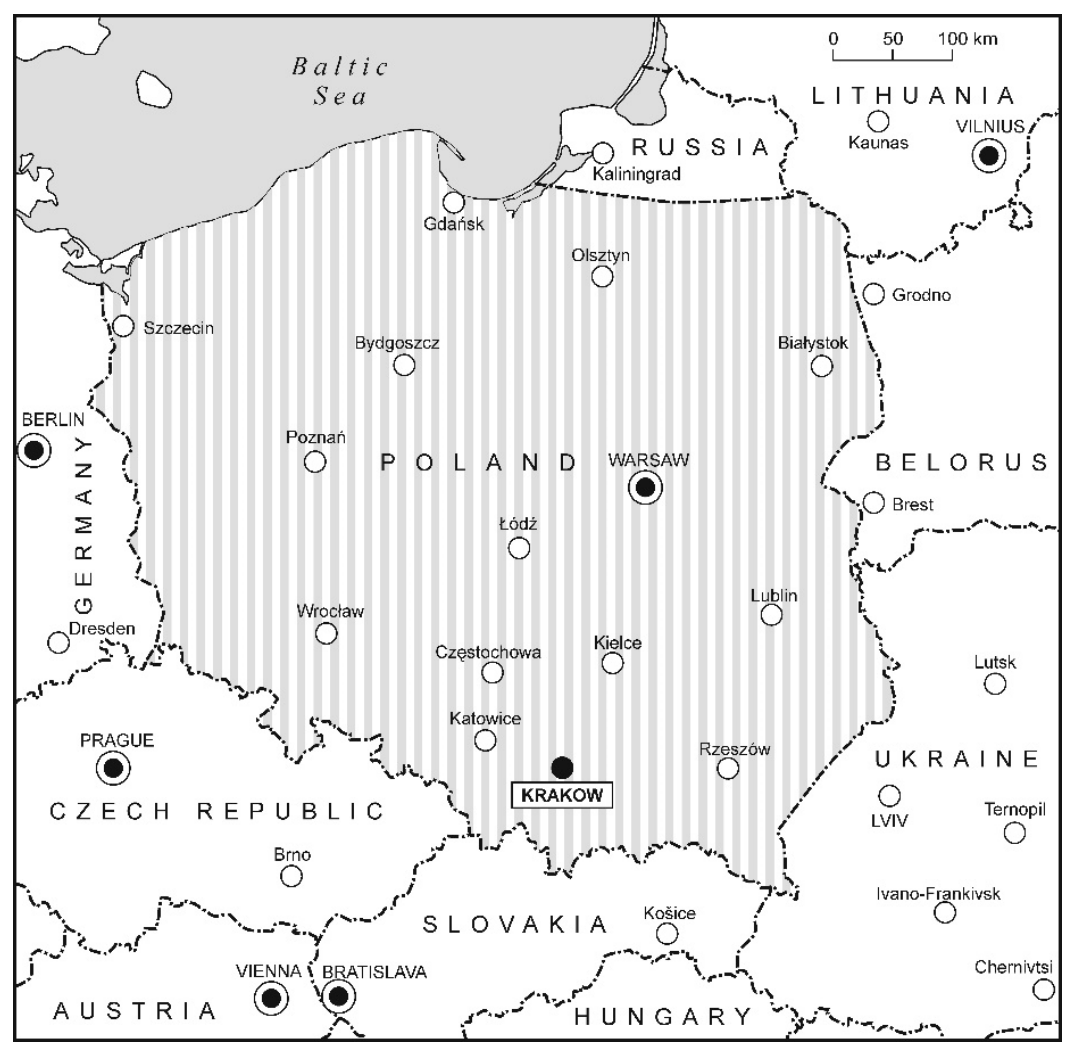

Figure 3. Localization of Kraków in Poland. Source: authors.

Like other cities in the CEE region, it experienced the political and economic transformation after 1989. With regard to post-socialist cities such as Kraków, this transformation has been characterized by a 'common logic' which has resulted in city center commercialization, inner city regeneration and outer city suburbanization [49]. In the case of Kraków, as well as of Prague or Budapest, the laissez-faire approach to tourism development also played a significant role in this transition [50-52]. Three decades after 1989, and 15 years after the accession to the European Union, Kraków has been branded as an attractive, viable city and the most important Polish center of tourism and modern business services $[53,54]$.

\subsection{Tourism in Kraków before COVID-19}

From the 1990s, Kraków, like other CEE cities, put an emphasis on stimulating the development of the tourism sector [24,54-57]. As a result, tourism has become an important part of the city's economy, providing almost 10\% of its GDP and around 40,000 jobs [58,59]. From 2004 to 2018, the registered accommodation capacity in Kraków more than doubled from 10,000 to 25,000 beds [60] (Figure 4). In 2019 about 10 million tourists and an additional 4 million one-day visitors visited the city, mostly from Poland (70\% of total) [58]. Such a great popularity on the domestic tourist market has resulted from the city being seen as the cultural capital of Poland $[23,54,57]$. For three million foreign tourists, the arrival at Kraków (in 2019) [58] involved not only visiting the heritage city, but also the Auschwitz-Birkenau Nazi concentration camp and the Wieliczka salt mine located nearby. All of them have an established position among world heritage sites (as part of the UNESCO program from the beginning) [61,62]. 


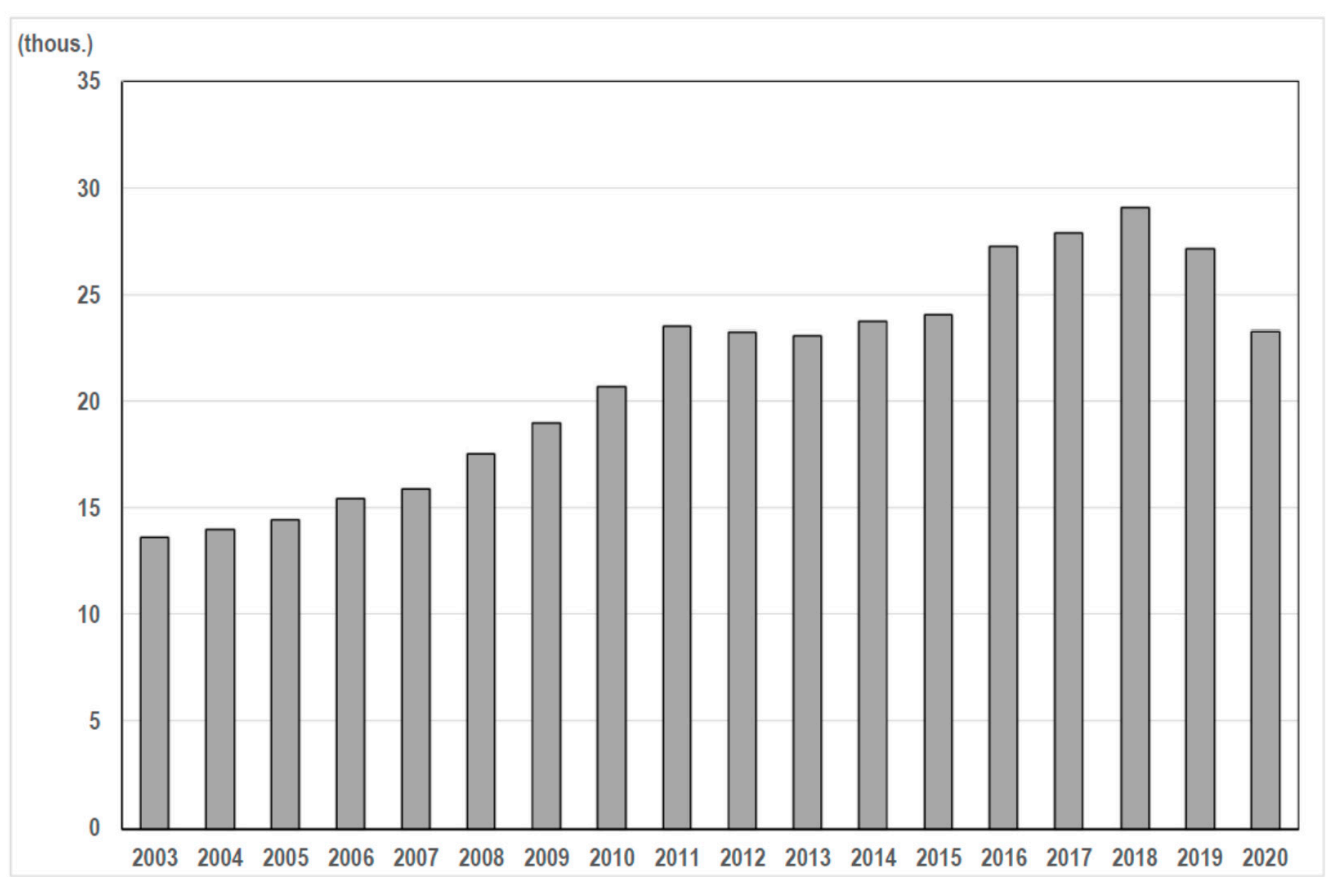

Figure 4. The capacity of tourist accommodation establishments: number of bed places in Kraków (2003-2020). Source: authors based on data from the Central Statistical Office [60].

Tourism in Kraków before the COVID-19 pandemic was characterized by seasonality and a relative lack of ties with the Małopolska Region [24,59]. Most tourists visited the city in the summer and stayed only in the city [59]. Only a small number of stays were combined with a visit to mountain tourist centers, like Zakopane $[58,63]$. The core tourist area in the city is the Old Town with the Royal Castle $[23,58,59]$. Alternative places visited by tourists are: the Jewish quarter in the Kazimierz district, the Podgórze district, and Nowa Huta, which is the former communist district with buildings in the style of socialist realism [23]. The number of tourists per inhabitant increased rapidly from 7 in 2004 to 17 in 2018 (Figure 5), while in central districts there were over 400 tourists per inhabitant per year, and 226 tourists per $\mathrm{km}^{2}$ [59].

The uncontrolled development of tourism in Kraków generated many socio-economic problems [64,65]. Local residents started to point to the need to modify the city's tourism policy [64-67]. In the first days of March 2020, an international conference on historical cities and tourism was held in the city. It was aimed at providing ways of developing tourism in conditions of overtourism $[68,69]$ but the formal lockdown was announced in Poland during this conference. The 'black swan' of COVID-19 [70] changed things fundamentally. At that time, no one thought how disastrous the COVID-19 pandemic would be for the tourism sector in Kraków and how it would affect the economy of the entire city. 


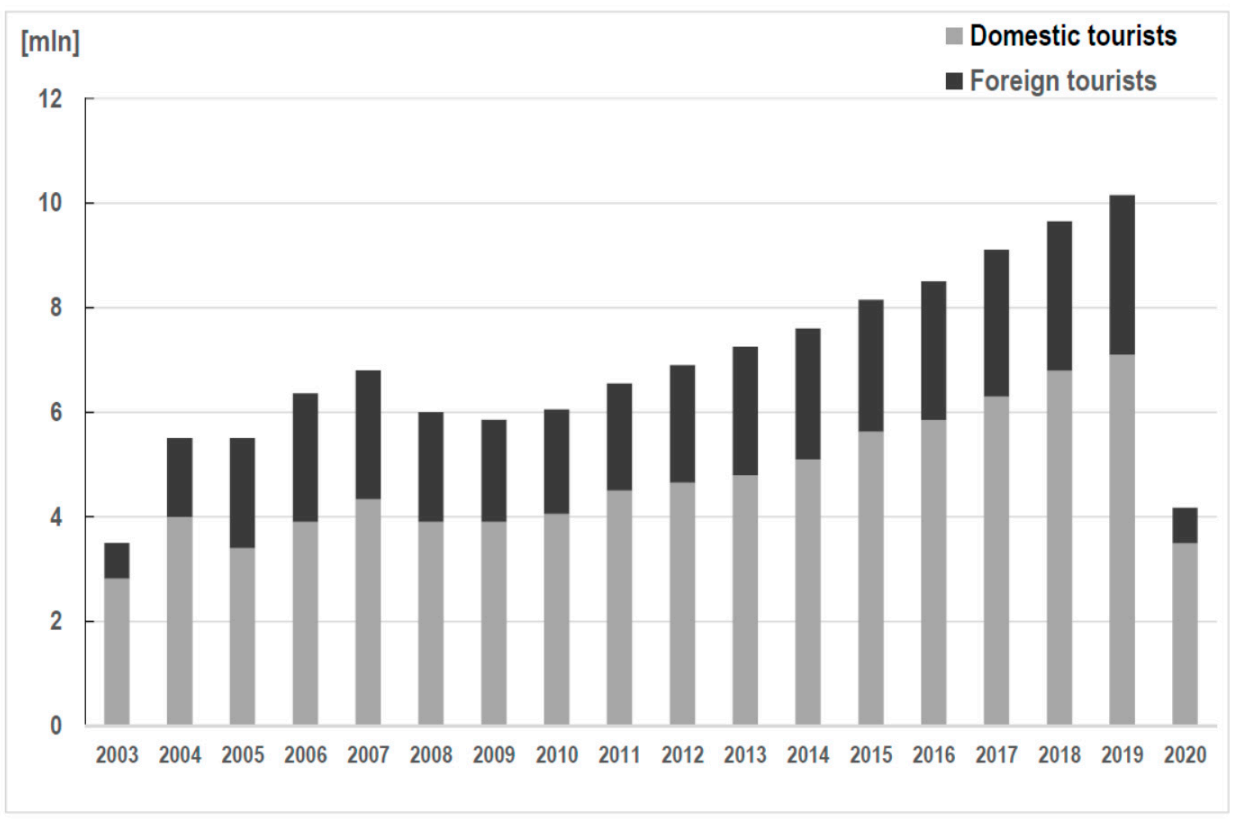

Figure 5. The number of domestic and foreign tourists in Kraków (2003-2020). Source: authors based on $[58,71]$.

\subsection{From Lockdown to Recovery}

First reports indicate that the tourism sector in Kraków suffered from COVID-19 very acutely $[67,72,73]$, and the situation turned from overtourism to undertourism [74]. Except for the first two months of 2020, when business was normal, the tourism sector could only partially offer its services. Due to travel restrictions enforced in other countries, coming to Kraków from abroad was significantly difficult [73]. Tourist arrivals to the city in the period from June until September/October 2020 were therefore mainly domestic [71].

The strong lockdown related to COVID-19 in Poland began to apply from mid-March 2020 [75], although the spatial extent of the COVID-19 was varied [75-77]. As in other countries, it was associated not only with the closing of state borders but with the introduction of restrictions on mobility and activity in many sectors of the economy [78]. In practice, from mid-March to the end of May 2020, the functioning of the tourism sector was very difficult indeed [78]. Accommodation facilities remained completely inaccessible to guests until the beginning of May, while gastronomy remained closed until the end of May 2020 [78].

In the period from June to the end of October 2020, there was a significant liberalization of activities in the tourism sector [78]. Hotels, gastronomy, culture and sports and recreation facilities were available without restrictions. Only nightclubs and discos remained closed. In the case of Kraków, this period can be considered as corresponding to the second stage described in the WTCF report.

Further economic closures occurred at the end of October and lasted until the end of 2020. Contrary to the first spring lockdown, the fall lockdown was not fully approved by the tourism industry [78]. Some entities operated despite bans using various legal tricks to circumvent regulations $[79,80]$. The scale was not significant, but it showed a growing resistance in the tourism sector to government regulations related to COVID-19.

In total, in 2020, Kraków was visited by 8 million people, of which tourists accounted for only 4.2 million [71]. The number of foreign tourists decreased by more than four times compared to 2019, from 3 million to 675,000 people. The number of domestic tourists in 2020 amounted to 3.5 million [71], and the number of domestic one-day visitors reached 3.5 million as well, practically unchanged compared to 2019 [71]. 


\subsection{How Kraków Responded to COVID-19}

The awareness of the high risk of COVID-19 for Kraków's tourism appeared relatively early [81]. After the first shock period in March 2020, which was often associated with radical limitations in relation to the level of threat at that time, the first attempts to counter the economic effects of the pandemic were implemented quite quickly. The first activities were of a grassroots nature, based on the exchange of information via social media, especially Facebook. Already by the end of March, local entrepreneurs directed their appeals to residents to support their activities. This was especially visible in the gastronomy sector, which reoriented its activity to delivering ready-made meals to the customer, and later also to the take-away formula. Moreover, there were appeals on the internet for people to order meals in restaurants, purchase items in non-chain grocery stores, and support local craft workshops. These initiatives served as a basis for the development of some local support programs coordinated by municipalities [82].

The actions of cities in response to the crisis were externally conditioned by Polish law [83]. Cities in followed, the main, the instructions and implemented the restrictions adopted by national authorities $[83,84]$. Their own initiative was limited, mainly due to financial constraints [84-86]. The authors have decided to present the response to COVID19 from three perspectives: the actions of the state, the actions of regional authorities and the actions of the city itself. Each of these relates to the stages highlighted in the WTCF report.

\subsubsection{Activities for the Local Tourism Industry: National Level}

In April 2020, the first financial support for the economy in Poland was launched (Anti-Crisis Shield) $[87,88]$. It was primarily intended to stop the collapse of businesses which, due to pandemic restrictions, could not operate [87]. These solutions served as an important framework for supporting tourism in Kraków during the pandemic [72,78]. The support system proposed by the government concerned mainly tax exemptions and direct financial support [88]. Its aim was to maintain the status quo in the market and prevent business failures and layoffs. Although the support system proposed by the government was quite broad, it did not fully meet the expectations of the tourism sector [78]. Firstly, it brought only short-term assistance, and secondly, it obliged entrepreneurs to keep workers on for a longer period of time, which was very risky from the point of view of the tourism business $[89,90]$. The size and scope of this financial aid was not sufficient $[90,91]$. Many types of tourism businesses were for a long time excluded from it, and the financial assistance implemented by the government was not positively assessed by the tourism industry [92].

The problems with shaping aid for the tourism sector are best illustrated by the example of tourism vouchers. In July 2020, the government program supporting holidays for families with children was introduced $[93,94]$. A voucher worth more than EUR 100 was given for each child and could be used to purchase services in Poland. As the tourism managers pointed out during official interviews, although the program was positively received by the industry, it quickly turned out that its practical implementation encountered a number of barriers and difficulties, often discouraging entrepreneurs from joining [95].

When assessing the government's support system for the tourism sector from the perspective of 2021, two issues should be noted. The support system was often developed ad hoc, without a long-term strategy and, equally important, without a comprehensive analysis of the needs and specificity of the tourism industry [96]. This created a sense of insecurity in receiving funds, often resulting in excessive bureaucracy. Importantly, however, it was observed that due to the pandemic, the tourism industry showed a greater willingness to cooperate and consolidate. Already in the middle of the year, sector committees were established at the government level in which representatives of the tourism industry sat alongside government officials [97]. Their goal was to develop new ideas of support for both individual entrepreneurs and the entire tourism sector. As a result, in 2021, advisory committees and councils were formally established at the ministry 
responsible for tourism and were in charge of setting the directions of the actions and tourism policy in Poland [97].

\subsubsection{Activities for the Local Tourism Industry: Regional Level}

The regional support system was important for the development of tourism in Kraków [98,99]. It should be noted that the extent of regional authority support for the tourism sector varied from region to region. In the case of Małopolska, to which Kraków belongs, the need to support the tourism sector was quickly identified, and the assistance focused on information support and promotional activities [99]. The information portal about possible forms of financial support from various sources should be considered a successful undertaking over the analyzed period. This resulted in a better preparation of the tourism sector for unstable conditions and provided information on possible support, as well as providing a steady flow of information between tourist entrepreneurs and voivodeship authorities.

Among other undertakings, the strengthening of cooperation between regional authorities, DMO and tourism industry chambers of commerce (e.g., the Kraków Chamber of Tourism) is worth mentioning. The regional authorities, together with the DMO, implemented a certificate of safe tourism in the region [100]. This program was aimed at supporting local entrepreneurs in their own fields and increasing their competitive advantages on the market. The certificate met with interest and a wide recognition from entrepreneurs. Another project was a joint advertising campaign aimed at the Polish market in order to attract tourists to Małopolska, including Kraków. The crisis of 2020 has significantly reoriented regional policy in the field of tourism, and the city has come to the attention of regional authorities. Based on their own budget, the regional authorities also organized competitions for grants aimed at supporting local tourist entrepreneurs. This support was obviously much smaller than national aid, and the chance to obtain it was limited due to the limited resources [101].

\subsubsection{Local Authority Action for Tourism Business}

The key conditions for the functioning of the tourism sector in Kraków during the COVID-19 period were shaped by the city authorities. Established tourist bodies included the Tourism Strategy Committee or the so-called 'Historical Heritage Round Table'. At the turn of 2019, the discussion about tourism in Kraków focused on extinguishing negative processes related to excessive tourism $[66,68,69]$. The city, even before the outbreak of the pandemic, had adopted a working set of actions aimed at changing its tourist image, limiting the negative effects of the night-time economy in the historic center [69] and managing heritage protection. It was assumed that from the beginning of May 2020, active measures would be taken in this regard. At the same time, important steps were taken for the tourism development strategy in Kraków in conditions of excessive tourist demand. The outbreak of the pandemic completely stopped both of these policies. Established task forces, consisting of representatives of officials, local entrepreneurs, the academic community and social organizations, were quick to shift their focus to the situation and challenges of tourism in COVID-19 conditions [72]. Particular attention was paid to financial support in the first weeks of the pandemic, when the tourism industry was in practice closed down.

In mid-April 2020, the city's Pauza business aid program [102] was officially launched, one of the first programs supporting the tourism sector from a city budget in Poland. This program lasted from 14 April to 30 June 2020 and provided extensive financial aid. It introduced a reduction in taxes and municipal rents, the suspension of payment deadlines, etc. The program also pointed to the need for the continuous monitoring of the financial condition of tourism enterprises in order to adjust the aid to actual needs. Many of the Pauza solutions were continued by the city after 30 June. It is estimated that the value of the aid provided by the city of Kraków during the pandemic amounted to over EUR 15 million, of which EUR 2 million related to a reduction in rents [103]. For the catering industry and café gardens, the reduction in rents for the lease of land and the reimbursement of fees for 
the license to sell alcohol was of great importance. As part of business support, internet platforms were also created to spread information about the actions taken and to promote Kraków entrepreneurs abroad.

\section{Creating a New City Image for Pandemic and Post-Pandemic Times}

In parallel to the above actions, decisions aimed at popularizing the city's tourist offerings in various markets were made. The condition for their success was the involvement of the local tourism sector in this process. The concept of micromarketing was adopted as a starting point, with the adjustment of activities to narrower target groups [98]. The campaigns implemented were targeted mainly at the domestic market. The first was addressed to the inhabitants of Kraków: the action 'Be a tourist in your own city' aimed at involving the inhabitants of Kraków in tourist consumption. The opportunity to visit museums and galleries as well as the use of restaurants when the city is not crowded with tourists was promoted. One of the elements of the campaign were the free tours around different parts of Kraków, led by local guides. The 'free tours for residents' campaign lasted until the end of October 2020. It is expected to start again in 2021 [104]. These activities not only benefited residents, but also employed local tourist guides who, in the conditions of a pandemic-hit city, faced relatively little demand. The aim of the program was to encourage people to use the city's tourist offer, with a $20 \%$ discount on local products, and it lasted for the entire holiday period of 2020, with more than 200 local companies and institutions taking part in it [104].

At the same time, the Kraków Undiscovered campaign was conducted in cooperation with a DMO on the Polish tourist market. Its aim was to promote Kraków among domestic tourists, and it included a strong advertising campaign in the largest cities of the country, namely Gdańsk, Wrocław, Poznań, Łódź, Szczecin and Warsaw, as well as advertisements in the media and on the internet [105]. Similar actions were taken by the Kraków authorities as part of their partnership cooperation with the seaside resort of Sopot, located by the Baltic Sea. These included the organization of promotional events, poster campaigns and other popularization activities. The idea was to increase interest in a city located on the other side of the country. There were no promotional campaigns on foreign markets. Only an information campaign, called 'Staying Safe in Kraków', was aimed at foreign tourists coming to the city [106].

\section{Local Cooperation for Tourism and New Tourism Programs for the Future}

The ever-changing conditions for the functioning of the tourism sector in the city required a constant exchange of information between the tourism office and local entrepreneurs [67]. The departments responsible for tourism monitored the situation throughout the pandemic period, and the results were used to develop the foundations of a tourism development strategy and to solve current problems. Not only the scale and character of tourism were analyzed, but also the state of local tourism businesses and transport, among other issues [72]. An important area of research was the social consequences of city nightlife, especially the noise and excessive alcohol consumption. Many temporary bodies dealing with various tourism issues, based on matrix organizational structures, have been established in the city. The work of these bodies was coordinated by the most important departments of the City Hall: the Tourism Department, the Culture Department, the Convention Bureau and the Kraków Festival Office. As a result, similarly to the national level, in Kraków there has been a tightening of the cooperation between city officials and local tourist business organizations (including the Kraków Chamber of Tourism) and between tourism, cultural and academic institutions. Not only was the exchange of information intensified, but a certain degree of openness to mutual suggestions and involvement in joint ventures was fostered.

Paradoxically, limiting the functioning of tourism in the city and slowing down the detrimental effects of tourism has allowed for a focus on planning for the future. It has led to the implementation of three important projects at the same time: 
1. Kraków's sustainable tourism policy for 2021-2028

2. Kraków Cultural Program, focused on the development of culture and heritage protection

3. Kraków Network Protocol.

The provisions of the strategic document for Kraków's sustainable tourism policy for 2021-2028 [67] will be of fundamental importance for the functioning of tourism in Kraków in the post-COVID-19 period. It is one of the first comprehensive documents in the CEE region setting out guidelines for the development of tourism after COVID-19 and has been approved by both the city authorities and local stakeholders in the tourism industry. As its authors emphasize, the implementation of the provisions of the document will be possible only in cooperation with the city authorities and with all partners from the public, social and private sectors, including city residents. The document's starting point is the idea of sustainable tourism. It is assumed that the challenge for Kraków in the process of rebuilding tourism will be city management, taking into account the commercialization of the offer, mitigating conflicts between residents and visitors, regulating access to selected parts of the city considered as touristic, as well as the involvement of residents with tourists.

Urban tourism management will focus on the nine basic problems identified by this program [67]). These recommendations were the result of a consultation with the most important stakeholders related to the tourism sector and were preceded by previous surveys among residents. Among them, the most important issues are (1) supporting the development of tailor-made products, (2) counteracting the effects of tourism hypertrophy and introducing the control of sharing economy development, (3) supporting the development of the MICE (Meetings, Incentives, Conferences and Exhibitions) Industry, (4) the integration of cultural and creative industries with tourism, (5) nightlife management, (6) a coherent management of tourism identity and reputation, (7) new technologies in tourism. This document was adopted in March 2021 and is currently in the operationalization phase.

The second area in which extensive planning activities were undertaken was the area of culture. The idea behind Kraków's Culture Program [107] is a broad range of actions which implement a multitude of tools, from very general to specific. This includes both actions taken in forming a new way of organizing and managing historic districts, especially the Old Town, and a new approach to the city's cultural offer and its connection with modern technologies. One such issue is linking the city's cultural offer with the tourist offer. Despite the great cultural potential, Kraków does not use its offer to build on its advantages on the tourist market. Every year, the city hosts a number of cultural events, but most of them go unnoticed by tourists. All this means that Kraków, which in 2000 had been a European city of culture, is still associated by tourists more with fun than with culture $[23,24,68,69,108]$.

The city's communication strategy in the field of culture will change. All cultural events will be grouped into four so-called seasons that will become a tourist brand of the city. Individual events will be promoted as part of a cultural season. Modern tools for the geolocation of events will be used. The city's cultural offer will include events in neighboring towns, which will expand the territorial range of the cultural offer for tourists. On the other hand, it is assumed that the promotion of Kraków's cultural offer will be intensified among the inhabitants of areas adjacent to the city [107].

The culture of Kraków is to be made constantly available on the internet. This is a consequence of the activities already carried out in the city by the play Kraków VOD platform. The platform is to become a window to the world of the city's culture, has been operating since the beginning of 2021 and is becoming more and more popular both at home and abroad. In the first months, it has offered a number of online events which during the pandemic took place without a live audience. In the future, the platform will include music shows, concerts, recitals, meetings with writers, as well as reports from other events, such as conferences, congresses, fairs and fashion shows taking place in Kraków. Another action taken by the city is the introduction of the Kraków Ticket Hub portal. It will be a virtual store providing access to all the city's cultural attractions, including last minute 
offers. Examples from other cities, such as Salzburg, show that the spontaneous decision to buy tickets for events is extremely important from the point of view of tourism.

The third document, the Kraków Network Protocol [109], is dedicated to business tourism. From the point of view of this economic field, the years 2020-2021 can be considered completely lost [67]. The MICE sector is characterized by the highest level of sensitivity to the risk of a pandemic, and the recovery process itself will be much longer than in the case of recreational tourism. Events are now happening exclusively online. In response to this situation, representatives of the MICE sector from Kraków, gathered under the Kraków Network Agreement, came up with the plan of developing ideas and a set of good practices in the field of congress tourism. The Kraków Network Protocol was created in 2021. The inspiration for its development was the Kaoshiung Protocol, developed by the International Congress and Convention Association [110]. The protocol is a collection of good practices and recommendations to be used in the new, pandemic reality [110]. This document is innovative and widely recognized on the international arena [110], while its recommendations have been recognized by the National Tourism Organization as exemplary in the tourism industry.

To sum up, in Kraków, the pandemic period has been used to create conditions for pandemic tourism and post-pandemic tourism. The main emphasis has been placed on the elimination of problem areas related to mass tourism, increasing the role of culture in shaping the tourism product, which in turn may affect the international brand of the city, as well as stimulating premium tourism market segments related to, inter alia, the organization and servicing of congresses. All the above-mentioned documents have become model solutions on a national scale, with the provisions they contain being analyzed and/or implemented in other Polish cities.

\section{Discussion and Conclusions}

In line with the research objectives, the article has presented measures and actions against COVID-19 proposed by the WTCF [21] which can be implemented at the urban level. In the empirical part, using the case study approach, Kraków's actions during the first year of struggle with the pandemic have been presented.

The actions presented in Kraków (and their local and national context) allow its situation to be compared to the recommendations contained in the WTCF report [21]. The authors are aware that the phenomenon investigated is in a state of constant change, but several conclusions can be drawn. Firstly, Kraków uses all the measures and actions against COVID-19 proposed by the WTCF [21] but to a differing extent. Moreover, secondly, the scale of mobilization by Kraków's authorities is visible in planning the tourist revival of Kraków in a 'new normal' and in setting these plans in motion. Thirdly, these actions (at least declaratively) are carried out with the involvement of stakeholders in Kraków's tourism industry while taking into account the interests of the community [111]. It should be emphasized that the problems of excessive tourism were relatively quite well identified in Kraków before COVID-19 [64,66,69] and had previously prompted the city authorities to seek new solutions to balance social and tourism needs. Such activities were quite popular among European cities [112] on the eve of the pandemic. Most focused on searching for a more sustainable way of managing tourism in the city (including the challenges of new phenomena such as a sharing economy in tourism). The case of Kraków is interesting in that the pandemic appeared at exactly the time of the discussion on overtourism, when the authorities had realized its potential problems. The tourism blockade 'opened up' city stakeholders (including the tourism and hospitality business) to the discussion on what to do to recover and how to recover. As a result, the attention of the tourism sector was 'captured' and proposals for new solutions aimed at seeking 'milder' forms of tourism were discussed. Of course, they may face local business resistance in a post-pandemic, which may be more interested in making up for losses regardless of prior arrangements. Such a possibility of returning to the 'business-as-usual' model in the post-pandemic phase of tourism development is indicated, among others, by Brouder [113]. 
Generally, the example of Kraków shows that within such cooperative mechanisms as temporary cross-departmental tasks forces [114], and public-private consolidation and collaboration, the time of the pandemic could be used both to mitigate losses and to discuss a new tourism model for the city. In Kraków, the result of these actions is the officially adopted new tourism development strategy [67]. The literature until now has no examples of similar planning activities in other tourism cities during the pandemic. Moreover, it should be emphasized that the case of Kraków to some extent confirms the assumptions of Vargas [32] that COVID-19 has given rise to a new model of tourism governance. It is unknown whether the mobilization observed in Kraków will bring about the expected results. Time will tell if Kraków really will go down the new path of sustainable tourism development indicated in the city documents.

It is difficult to compare Kraków's responses to COVID-19 in relation to other tourism cities, because, as previously emphasized, such studies, apart from the WTCF report and several papers mainly concerning Macao [10,18-20], are not yet available. The example of Macao (casino-city) shows that the economic resilience of a destination is essential for its social resilience [10] and allows for a quick release of financial reserves as aid funds for the tourism sector and the local community. It also shows that the recovery wave should move to public-private consolidation and collaboration [18], which has partially been found in Kraków as well. At the same time, to understand the Macao context, it is necessary to emphasize the extreme nature of the tourism economy for this destination (50.3\% of GDP is from tourism [10]) and its strong dependence on Chinese visitors, as well as the determination to quickly restart and re-open for visitors $[10,18,20]$. Above all, however, Macao used its previous experience to deal with epidemic crises. In this respect, Kraków, but also most tourism cities, especially in CEE, function in different economic and geopolitical realities. However, the common challenge of most tourism cities, including Kraków and Macao, is the fact that tourism, due to its economic and social role in the local economy, has become 'too big to fail' [115]. The case of Macao also suggests to tourism cities, including CEE and heritage cities such as Kraków, that crisis management should become a priority in strategic planning, especially when the aim is sustainable.

Learning from the experience of a pandemic is now an obvious necessity [86], especially for shaping sustainable urban destinations. The wide spectrum of activities undertaken in Kraków gives the city the opportunity to evaluate and revise them in retrospect, as well as to be appropriate and effective. It can also be a stimulus for building a further vision of development and strengthening the city's resilience. The case of Kraków is particularly important not only for CEE tourism cities (where, as shown in Lviv by Rutynskyi and Kushniruk [116], the need to support the tourism industry was much less noticed), but also historical cities that can, in new circumstances, build their own resilience and (re)shape a competitive advantage based on the potential of cultural heritage.

One of the most frequently emphasized and spectacular responses to the COVID19 crisis, indicated both in the WTCF report [21] and in the activities of Kraków, is the observed change in the area of culture. A visible turn in a pandemic time, following Agostino et al. [117], can be called a transition 'from onsite closure to online openness'. Upon their physical closure, various cultural institutions, such as museums and galleries, have started spreading online access to culture and knowledge. An increasing number of museums (e.g., Italian state museums in Venice, Rome and Naples) are using social media to reach wider online audiences through sharing free virtual tours, descriptions of artworks, as well as setting up quizzes and treasure hunts [117]. A great example of free engagement with culture in a wider tourism city context comes from Buenos Aires, where 'the municipality, together with UNESCO, launched the 'Cultura en Casa' project to provide rich cultural contents for adults and children. Materials are free to everyone and include opera, ballet, virtual visits to museums and galleries, audiobooks and television series' [21]. The above examples show not only the use of the newest ICT tools to popularize culture and cultural tourism, but also to illustrate the implementation of a new approach to culture and social development [118]. According to these assumptions, cultural inclusion can reduce 
social inequalities and, at the same time, contribute to the post-pandemic re-opening. EU action can serve as an example of an institutional approach to these issues. The European path to a safe and sustained re-opening adopted in March 2021 has a special financial tool, 'The European Regional Development Fund 2021-2027', which is aiming to support economic development and social inclusion in culture and tourism [119].

The Kraków case study, in accordance with the assumptions of an exploratory case study [22], allows for the formulation of questions for further research. In particular, the following issues seem attractive for future research on tourism cities and COVID-19:

1. Will the city's tourism offering be revised and become more sustainable? Will postpandemic tourism cities become sustainable tourism destinations and thus become better places to live? As many academics expect [14-16], post-pandemic tourism should be more sustainable, and tourist destinations should base their development patterns on sustainable development goals. On the other hand, the practice to date, especially in urban environments, and despite many declarations, has been strongly connected with growth strategies that were strengthening urban tourism hypertrophy [115]. Will the experience of the pandemic crisis and the corrective actions discussed and/or implemented effectively change this? Or are the sceptics who predict the return of 'business as usual' right?

2. Will culture be a real driver for a post-covid tourism city? And, if so, to what extent? How will the new technological improvements in culture be received by their participants? What will the trajectories of technology acceptance be between different groups (e.g., generations) of recipients (such as cultural visitors)? What will the absorption of new cultural offerings by local communities be? Will any changes become permanent? Murzyn-Kupisz and Hołuj [108] previously indicated that the negative impacts of overtourism can be mitigated to some extent by museums. Will the introduced solutions allow for the effective management of cultural urban attractions that previously carried the stigma of overcrowding and a reduced experience for cultural participants?

3. Will 'being a tourist in one's own city', promoted during the pandemic, become a permanent model of leisure activity for inhabitants of tourism cities? Richards [120,121] sees the new practices of cultural tourism in this form. Is it just a temporary fashion or will a permanent new trend develop? A close and important issue related to these questions is destination (tourism city) resilience: will the local demand for culture and leisure be effective in building destination resilience and setting new (e.g., co-creation) frameworks for shaping the relationship between residents and visitors? Finally, referring to the ideas for social inclusion through culture and tourism [122]: will such activities be a driver for strengthening the cultural capital of the local community or will the cultural turn of cities depend on community cultural and social capital?

4. The reactions of tourists and other city users to the changes in the tourism city introduced by, and thanks to, the pandemic seem to be equally interesting. Will city tourists absorb and accept the proposed changes? What changes do they expect themselves to see in post-pandemic tourism cities?

5. It is also worth referring to the CEE context. Will the support for tourism received in CEE cities allow for the revival of this sector? Which direction will post-pandemic tourism take in CEE cities? Will there be a change in the approach to tourism development in CEE cities, or will laissez-faire still be practiced? Will a model based on growth in international city-break tourism in CEE historical cities be revised? It is also interesting how the pandemic has influenced relations between tourism stakeholders in these destinations. Have they managed, as shown in Kraków, to constitute a front of cooperation between public and private tourism stakeholders? The case of post-Soviet Samarkand (not CEE, but Uzbekistan's tourism city), described by Wróblewski et al. [123], shows that the challenges may be found in the local tourism industry's reluctance to cooperate with the authorities, the weaknesses of the organizations that represent the industry, as well as a belief that businesses must solve 
pandemic-related problems on their own. In other words, with regard to CEE tourism cities, an attractive direction for post-covid research seems to be related to their still ongoing transition and the issue of shaping (institutional and non-institutional) cooperation. As it follows from institutional theory [124], the effectiveness of regulatory and recovery actions depends on the coexistence and mutual support of formal and informal institutions.

In summary, it can be noted that the strength of this paper stems from the confrontation of previously theoretical assumptions and recommendations with an in-depth case study of actually implemented actions taken in specific urban conditions. The case study has also opened new possibilities for building knowledge and formulating further research questions. At the same time, the limitations of this paper should be mentioned. They are embedded in the case study approach, especially in its non-routine research procedures [22]. They are also related to the very limited nature of the available information sources and the limited scope of research to date (such as case studies of other cities) for making comparisons. To a large extent, the limitations result from the novelty of the analyzed phenomenon, including the rapidly changing situation and the complexity of relations between the city and tourism during a still ongoing worldwide pandemic.

Author Contributions: Conceptualization, J.K.-A. and R.P.; methodology, J.K.-A. and R.P.; formal analysis, J.K.-A. and R.P.; resources, M.G., R.P. and J.K.-A.; writing-original draft preparation, J.K.-A. and R.P.; writing-review \& editing, J.K.-A. and R.P.; visualization, J.K.-A. and R.P.; supervision, J.K.-A. and R.P. All authors have read and agreed to the published version of the manuscript.

Funding: This research has been supported by Institute of Urban and Regional Development (Warsaw, Poland).

Institutional Review Board Statement: Not applicable.

Informed Consent Statement: Not applicable.

Data Availability Statement: Not applicable.

Conflicts of Interest: The authors declare no conflict of interest. The funders had no role in the design of the study; in the collection, analyses, or interpretation of data; in the writing of the manuscript, or in the decision to publish the results.

\section{References}

1. Henderson, J.C. Communicating in a crisis: Flight SQ 006. Tour Manag. 2003, 24, 279-287. [CrossRef]

2. Laws, E.; Prideaux, B. Tourism Crises: Management Responses and Theoretical Insight; Routledge: London, UK; New York, NY, USA, 2005; ISBN 0-7890-3208-2.

3. McKercher, B.; Hui, E.L. Terrorism, economic uncertainty and outbound travel from Hong Kong. J. Travel Tour. Mark. 2004, 15, 99-115. [CrossRef]

4. Wut, T.M.; Xu, J.B.; Wong, S.M. Crisis management research (1985-2020) in the hospitality and tourism industry: A review and research agenda. Tour. Manag. 2021, 85, 104307. [CrossRef]

5. Gössling, S.; Scott, D.; Hall, C.M. Pandemics, tourism, and global change: A rapid assessment of Covid-19. J. Sustain. Tour. 2020, 29, 1-20. [CrossRef]

6. Ritchie, B.W.; Jiang, Y. A review of research on tourism risk, crisis, and disaster management. Ann. Tour Res. 2019, 79. [CrossRef]

7. Collins-Kreiner, N.; Ram, Y. National tourism strategies during the Covid-19 pandemic. Ann. Tour Res. 2020, 103076. [CrossRef] [PubMed]

8. UNTWO. Worst Year in Tourism History with 1 Billion Fewer International Arrivals. 2021. Available online: https://www.unwto. org/news / 2020-worst-year-in-tourism-history-with-1-billion-fewer-international-arrivals (accessed on 15 May 2021).

9. Pescaroli, G.; Alexander, D. Critical infrastructure, panarchies and the vulnerability paths of cascading disasters. Nat. Hazards 2016, 82, 175-192. [CrossRef]

10. McCartney, G.; Pinto, J.; Liu, M. City resilience and recovery from COVID-19: The case of Macao. Cities 2021, 112, 103130. [CrossRef]

11. Dolnicar, S.; Zare, S. COVID19 and Airbnb: Disrupting the disruptor. Ann. Tour. Res. 2020. [CrossRef]

12. Visacovsky, S.E.; Zenobi, D.S. When a crisis is embedded in another crisis. Soc. Anthropol. 2020, 28. [CrossRef]

13. Tourism Economics, City Tourism Outlook and Ranking: Coronavirus Impacts and Recovery. Available online: https:/ / resources. oxfordeconomics.com/hubfs/City-Tourism-Outlook-and-Ranking.pdf (accessed on 15 April 2020). 
14. Sigala, M. Tourism and COVID-19: Impacts and implications for advancing and resetting industry and research. J. Bus. Res. 2020, 117, 312-321. [CrossRef]

15. Sharma, G.D.; Thomas, A.; Paul, J. Reviving tourism industry post-COVID-19: A resilience-based framework. Tour. Manag. Perspect. 2021, 37, 100786. [CrossRef]

16. Persson-Fischer, U.; Liu, S. The Impact of a Global Crisis on Areas and Topics of Tourism Research. Sustainability 2021, 13, 906. [CrossRef]

17. Davahli, M.R.; Karwowski, W.; Sonmez, S.; Apostolopoulos, Y. The Hospitality Industry in the Face of the COVID-19 Pandemic: Current Topics and Research Methods. Int. J. Environ. Res. Public Health 2020, 17, 7366. [CrossRef]

18. McCartney, G. The impact of the coronavirus outbreak on Macao. From tourism lockdown to tourism recovery. Curr. Issues Tour. 2020. [CrossRef]

19. Li, Z.; Zhang, X.; Yang, K.; Singer, R.; Cui, R. Urban and rural tourism under COVID-19 in China: Research on the recovery measures and tourism development. Tour. Rev. 2021. [CrossRef]

20. Lim, W.M.; To, W.M. The economic impact of a global pandemic on the tourism economy: The case of COVID-19 and Macao's destination-and gambling-dependent economy. Curr. Issues Tour. 2021. [CrossRef]

21. WCFT. Report on Recovery and Development of World Tourism Amid COVID-19. Available online: https://en.wtcf.org.cn/ Research/WTCFAcademicAchievement/2020091419631.htm (accessed on 14 September 2020).

22. Yin, R.K. Case Study Research, Design and Method, 4th ed.; Sage Publications Ltd.: London, UK, 2009; ISBN 978-1412960991.

23. Pawlusiński, R.; Kubal-Czerwińska, M. A new take on an old structure? Creative and slow tourism in Krakow (Poland). J. Tour. Cult. Chang. 2018, 16, 265-285. [CrossRef]

24. Mika, M.; Kurek, W. Ocena i perspektywy rozwoju Krakowa jako ośrodka turystycznego. In Kraków Jako Ośrodek Turystyczny; Mika, M., Ed.; Instytut Geografii i Gospodarki Przestrzennej UJ: Kraków, Poland, 2011; pp. 291-304, ISBN 978-83-88424-60-1.

25. Creswell, J.W. Research Design: Qualitative, Quantitative, and Mixed Methods Approaches, 4th ed.; Sage Publications, Inc.: Thousand Oaks, CA, USA, 2009; ISBN 978-1-4522-2609-5.

26. Thomas, G. A typology for the case study in social science following a review of definition, discourse, and structure. Qual. Inq. 2011, 17, 511-521. [CrossRef]

27. Shareef, S.; Altan, H. Assessing the Implementation of Renewable Energy Policy within the UAE by Adopting the Australian 'Solar Town' Program. Future Cities Environ. 2019, 5, 1-11. [CrossRef]

28. Stake, R.E. The Art of Case Study Research; Sage: Thousand Oaks, CA, USA, 1995; ISBN 978-0803957671.

29. Cheshmehzangi, A. 10 Adaptive Measures for Public Places to face the COVID 19 Pandemic Outbreak. City Soc. 2020, 32. [CrossRef]

30. Costa, D.G.; Peixoto, J.P.J. COVID-19 pandemic: A review of smart cities initiatives to face new outbreaks. IET Smart Cities 2020, 2, 64-73. [CrossRef]

31. Petrović, N.N.; Dimovski, V.; Peterlin, J.; Meško, M.; Roblek, V. Data-Driven Solutions in Smart Cities: The case of Covid-19 Apps. In Proceeding of the WWW '21: Companion Proceedings of the Web Conference 2021, Ljubljana, Slovenia, 19-23 April 2021; pp. 648-656. [CrossRef]

32. Vargas, A. Covid-19 crisis: A new model of tourism governance for a new time. Worldw. Hosp. Tour. Themes 2020, 12, 691-699. [CrossRef]

33. Fedyk, W.; Sołtysik, M.; Oleśniewicz, P.; Borzyszkowski, J.; Weinland, J. Human resources management as a factor determining the organizational effectiveness of DMOs: A case study of RTOs in Poland. Int. J. Contemp. Hosp. Manag. 2021, 33, 828-850. [CrossRef]

34. Gallego, I.; Font, X. Changes in air passenger demand as a result of the COVID-19 crisis: Using Big Data to inform tourism policy. J. Sustain. Tour. 2020. [CrossRef]

35. Pasquinelli, C.; Trunfio, M.; Bellini, N.; Rossi, S. Sustainability in Overtouristified Cities? A Social Media Insight into Italian Branding Responses to Covid-19 Crisis. Sustainability 2021, 13, 1848. [CrossRef]

36. Kowalczyk-Anioł, J.; Nowacki, M. Factors influencing Generation Y's tourism-related social media activity: The case of Polish students. J. Hosp. Tour. Technol. 2020, 11, 543-558. [CrossRef]

37. Fennell, D.A. Technology and the sustainable tourist in the new age of disruption. J. Sustain. Tour 2021, 29, 767-773. [CrossRef]

38. Gretzel, U.; Fuchs, M.; Baggio, R.; Hoepken, W.; Law, R.; Neidhardt, J.; Pesonen, J.; Zanker, M.; Xiang, Z. e-Tourism beyond COVID-19: A call for transformative research. Inf. Technol. Tour. 2020, 22, 187-203. [CrossRef]

39. Zeng, Z.; Chen, P.J.; Lew, A.A. From high-touch to high-tech: COVID-19 drives robotics adoption. Tour. Geogr. 2020, $22,1-11$. [CrossRef]

40. Kwok, A.O.; Koh, S.G. COVID-19 and extended reality (XR). Curr. Issues Tour. 2020. [CrossRef]

41. Bec, A.; Moyle, B.; Schaffer, V.; Timms, K. Virtual reality and mixed reality for second chance tourism. Tour. Manag. 2021, 83, 104256. [CrossRef]

42. Min, J.C. The effect of the SARS illness on tourism in Taiwan: An empirical study. Int. J. Manag. 2005, 22, 497-506. [CrossRef]

43. Nhamo, G.; Dube, K.; Chikodzi, D. Counting the Cost of COVID-19 on the Global Tourism Industry; Springer: Cham, Switzerland, 2020; pp. 377-402, ISBN 978-3-030-56231-1. 
44. European Union. Tourism and Transport: Commission's Guidance on How to Safely Resume Travel and Reboot Europe's Tourism in 2020 and Beyond. 2020. Available online: https:/ / europeansting.com/2020/05/13/tourism-and-transport-commissionsguidance-on-how-to-safely-resume-travel-and-reboot-europes-tourism-in-2020-and-beyond/ (accessed on 15 February 2021).

45. Hao, F.; Xiao, Q.; Chon, K. COVID-19 and China's hotel industry: Impacts, a disaster management framework, and post-pandemic agenda. Int. J. Hosp. Manag. 2020, 90, 102636. [CrossRef]

46. WTTC. 'Safe Travels': Global Protocols \& Stamp for the New Normal. 2020. Available online: https://wttc.org/COVID-19/SafeTravels-Global-Protocols-Stamp (accessed on 15 February 2021).

47. Statistical Office in Krakow. Available online: http:/ / krakow.stat.gov.pl/en/ (accessed on 5 June 2021).

48. Purchla, J. Kraków Prowincja Czy Metropolia? Universitas: Kraków, Poland, 1996; ISBN 8370523900.

49. Sýkora, L.; Bouzarovski, S. Multiple transformations: Conceptualising the post-communist urban transition. Urban Stud. 2012, 49, 43-60. [CrossRef]

50. Smith, M.K.; Puczkó, L. Post-Socialist Tourism Trajectories in Budapest: From Under-Tourism to Over-Tourism. In Tourism Development in Post-Soviet Nations; Slocum, S.L., Klitsounova, V., Eds.; Palgrave Macmillan: London, UK, 2020; pp. 109-123, ISBN 978-3-030-30717-2.

51. Kowalczyk-Anioł, J. Tourismification of the Housing Resources of Historical Inner Cities. The Case of Krakow. Studia Miejskie 2019, 35, 9-25. Available online: https:/ / depot.ceon.pl/handle/123456789/19361 (accessed on 20 November 2020). [CrossRef]

52. Kádár, B. Hotel development through centralized to liberalized planning procedures: Prague lost in transition. Tour. Geogr. 2018, 20, 461-480. [CrossRef]

53. Romańczyk, K.M. Krakow-The city profile revisited. Cities 2018, 73, 138-150. [CrossRef]

54. Pawlusiński, R.; Kubal, M. Tradycje turystyczne Krakowa. In Kraków Jako Ośrodek Turystyczny; Mika, M., Ed.; Instytut Geografii i Gospodarki Przestrzennej UJ: Kraków, Poland, 2011; pp. 35-36, ISBN 978-83-88424-60-1.

55. Smith, M.K.; Klicek, T. Tourism Cities in Post-Communist Countries. In Routledge Handbook of Tourism Cities, 1st ed.; Morrison, A.M., Coca-Stefaniak, J.A., Eds.; Routledge: London, UK, 2020; pp. 493-507, ISBN 978-042-924-460-5.

56. Szubert-Zarzeczny, U. Turystyka w Rozwoju Gospodarczym Polski; Wyd. Wyższej Szkoły Zarządzania „Edukacja”: Wrocław, Poland, 2002; ISBN 838770895X.

57. Kurek, W.; Faracik, R. Selected issues in the development of tourism in Krakow in the 21th century. Tourism 2008, 18, 65-82.

58. Borkowski, K.; Grabiński, T.; Seweryn, R.; Rotter, L.; Mazanek, L.; Grabińska, E. Ruch Turystyczny w Krakowie w 2019 Roku; Monografia; Malopolska Organizacja Turystyczna: Kraków, Poland, 2020; ISBN 978-83-66288-56-0.

59. Borkowski, K.P. Triangulacja Subiektywnych Odczuć Osób Wypoczywających w Krakowie w Aspekcie Poczucia Bezpieczeństwa Osobistego Podczas Rekreacyjnego Pobytu w Destynacji. Badania Diagnostyczne 2008-2018; Małopolska Organizacja Turystyczna: Krakow, Poland, 2019; ISBN 978-83-66029-99-6.

60. Central Statistical Office. Kraków: Statistical Data, 2021, Warsaw, Poland. Available online: www.bdl.stat.gov.pl (accessed on 1 June 2021).

61. Jokilehto, J. The World Heritage List. What Is OUV? Defining the Outstanding Universal Value of Cultural World Heritage Properties; International Council on Monuments and Sites: Paris, France, 2008; ISBN 978-3-930388-51-6. Available online: http:/ / openarchive. icomos.org/id/eprint/435/1/Monuments_and_Sites_16_What_is_OUV.pdf (accessed on 20 November 2020).

62. Kowalska, S. Cultural Heritage in Poland — the Background, Opportunities and Dangers; Uniwersytet im. Adama Mickiewicza w Poznaniu: Poznań-Kalisz, Poland, 2012; ISBN 978-83-62135-55-4.

63. Pawlusiński, R. International inbound tourism to the Polish Carpathians-The main source markets and their growth opportunities. Acta Fac. Studiorum Humanit. Nat. Univ. Prešoviensis Prírodné Vedy Folia Geogr. 2015, 2. Available online: http:/ / www.foliageographica.sk/public/media/27015/2 (accessed on 20 November 2020).

64. Zmyślony, P.; Kowalczyk-Anioł, J. Urban tourism hypertrophy: Who should deal with it? The case of Krakow (Poland). Int. J. Tour. Cities 2019, 5, 247-269. [CrossRef]

65. Zmyślony, P.; Kowalczyk-Anioł, J.; Dembińska, M. Deconstructing the overtourism-related social conflicts. Sustainability 2020, 12, 1695. [CrossRef]

66. Kruczek, Z. Turyści vs. Mieszkańcy. Wpływ Nadmiernej Frekwencji Turystów na Proces Gentryfikacji Miast Historycznych na Przykładzie Krakowa. Turystyka Kulturowa 2018, 3, 29-41. Available online: http://turystykakulturowa.org/ojs/index.php/tk/ article/view/956 (accessed on 20 November 2020).

67. Polityka Zrównoważonej Turystyki Krakowa na lata 2021-2028 [Sustainable Tourism Policy in Kraków 2021-2028], Urząd Miasta Krakowa [Krakow City Council], Kraków 2021. Available online: https://www.bip.krakow.pl/_inc/rada/posiedzenia/show_ pdfdoc.php?id=117239\&_ga=2.182696230.1617955323.1620064872-98079949.1616671209 (accessed on 15 March 2021).

68. Szromek, A.; Kruczek, Z.; Walas, B. The Attitude of Tourist Destination Residents towards the Effects of Overtourism-Kraków Case Study. Sustainability 2020, 12, 228. [CrossRef]

69. Pawlusiński, R.; Mróz, K.; Grochowicz, M. Rozwój gospodarki nocnej w miastach historycznych-Aspekty przestrzenne. Przykład krakowskiej dzielnicy Kazimierz. Konwersatorium Wiedzy Mieście 2020, 5, 55-70. [CrossRef]

70. Taleb, N.N. The Black Swan: The Impact of the Highly Improbable, 2nd ed.; Random House: New York, NY, USA, 2010; ISBN 978-0812973815.

71. Urzad Miasta Krakowa [City of Krakow]. Ruch Turystyczny w Krakowie w 2021 [Tourism in Krakow 2021], Department of Tourism. 2021. Available online: https:/ / www.bip.krakow.pl/?sub_dok_id=58088 (accessed on 15 March 2021). 
72. Walas, B.; Kruczek, Z. The impact of COVID-19 on tourism in Kraków in the eyes of tourism entrepreneurs. Studia Perieget. 2020, 2, 79-95. Available online: http:/ / cejsh.icm.edu.pl/cejsh/element/bwmeta1.element.ceon.element-72ad3faa-9566-3f86-be0e733ebda5035e (accessed on 15 March 2021). [CrossRef]

73. Korinth, B.; Ranasinghe, R. Covid-19 pandemic's impact on tourism in Poland in March 2020. Geoj. Tour. Geosites 2020, 31, 987-990. [CrossRef]

74. Milano, C.; Koens, K. The paradox of tourism extremes. Excesses and restraints in times of COVID-19. Curr. Issues Tour. 2021. [CrossRef]

75. Jarynowski, A.; Wójta-Kempa, M.; Płatek, D.; Krzowski, Ł.; Belik, V. Spatial Diversity of COVID-19 Cases in Poland Explained by Mobility Patterns-Preliminary Results. SSRN 2020. [CrossRef]

76. Duszyński, J.; Afelt, A.; Ochab-Marcinek, A.; Owczuk, R.; Pyrć, K.; Rosińska, M.; Rychard, A.; Smiatacz, T. Understanding COVID-19. Report by the Covid-19 Advisory Team to the President of the Polish Academy of Sciences, Polish Academy of Sciences: Warsaw, Poland, 14 September 2020. Available online: https:/ /institution.pan.pl/images/Understanding_COVID-19 _final_version.pdf (accessed on 15 March 2021).

77. Krzysztofik, R.; Kantor-Pietraga, I.; Spórna, T. Multidimensional Conditions of the First Wave of the COVID-19 Epidemic in the Trans-Industrial Region. An Example of the Silesian Voivodeship in Poland. Sustainability 2021, 13, 4109. [CrossRef]

78. Grochowicz, M. Sytuacja Branży Gastronomicznej w Pierwszych Miesiącach Trwania Pandemii COVID-19 na Przykładzie Krakowa. Urban Dev. Issues 2020, 67, 5-16. Available online: http://obserwatorium.miasta.pl/wp-content/uploads/2020/11/ UDI67_Grochowicz.pdf (accessed on 15 March 2021). [CrossRef]

79. Dziadosz, P.; Banasik, M. Gastronomia ma dość Lockdownu. Krakowskie Restauracje Otwierają się Mimo Zakazu. Krakow Nasze Miasto. Information Portal KrakowNasze Miasto.pl, 13 January 2021. Available online: https://krakow.naszemiasto.pl/ gastronomia-ma-dosc-lockdownu-krakowskie-restauracje/ar/c1-8084495 (accessed on 15 March 2021).

80. Kołodziejczyk, K. Koronawirus im Niestraszny. Kolejne Restauracje Otwierają się dla Klientów, WP Info Portal, 13 January 2021. Available online: https:/ / wiadomosci.wp.pl/koronawirus-im-niestraszny-kolejne-restauracje-otwieraja-sie-dla-klientow-65 96717755784064a (accessed on 15 March 2021).

81. Dziennik Polski [Daily Local Paper]. Czarny Scenariusz dla Krakowa: Tysiące Firm Przetrwa Kryzys, Ale Zostanie Bez Klientów. Rząd im nie Pomoże. Lepsze Wieści Dla Podhala, May 2020. Available online: https:/ /dziennikpolski24.pl/czarny-scenariuszdla-krakowa-tysiace-firm-przetrwa-kryzys-ale-zostanie-bez-klientow-rzad-im-nie-pomoze-lepsze-wiesci-dla/ar/c3-1499588 7 (accessed on 15 March 2021).

82. Krakow.pl. [Official Business Portal. City of Krakow]. Mapa Krakowskiej Gastronomii ma Już Miesiąc! November 2020. Available online: https://business.krakow.pl/informacje_na_temat_dzialan_i_projektow_umk/244658,1643,komunikat,mapa_ krakowskiej_gastronomii_ma_juz_miesiac_.html (accessed on 15 March 2021).

83. Augustyniak, M. Samorzad Terytorialny w ŚWIETLE wybranych Regulacji Ustawy COVID-19 i jej Zmian; Wolters Kluwer: Warszawa, Poland, 2020; ISBN 978-83-8187-988-0.

84. Dębkowska, K.; Kłosiewicz-Górecka, U.; Szymańska, A.; Ważniewski, P.; Zybertowicz, K. Polskie Miasta w Czasach Pandemii; Polski Instytut Ekonomiczny: Warszawa, Poland, 2020; ISBN 978-83-66698-08-6.

85. Grochowicz, M.; Salata-Kochanowski, P. Działania Miast Podczas Pandemii; Ekspertyzy i Opracowania Badawcze, Obserwatorium Polityki Miejskiej, Instytut Rozwoju Miast i Regionów: Warszawa-Kraków, Poland, 2020; Available online: http: / / obserwatorium. miasta.pl/dzialania-miast-podczas-pandemii-raport/ (accessed on 15 March 2021).

86. Pomiędzy Nadzwyczajnymi Zadaniami a Ograniczonymi Możliwościami-Samorząd Terytorialny w Czasie Pandemii; Raport Samorząd, Open'20 Eyes Economy Summit; Fundacja Gospodarki i Administracji Publicznej: Kraków, Poland, 2020; Available online: https:/ / oees.pl/wp-content/uploads/2020/10/Raport-samorzad.pdf (accessed on 15 March 2021).

87. Stojczew, K. Ocena wpływu pandemii koronawirusa na branżę turystyczną w Polsce. Prace Nauk. Uniw. Ekon. Wrocławiu 2021, 65, 157-172. [CrossRef]

88. Juszczak, A. Trendy Rozwojowe Turystyki w Polsce Przed i w Trakcie Pandemii COVID-19; Report, PARP Grupa PFR; Instytut Turystyki w Krakowie sp. z.o.o.: Krakow, Poland, 2020; Available online: https://www.silesia-sot.pl/wp-content/uploads/2021/01/ Ekspertyza_Trendy-rozwojowe-turystyki-w-Polsce-przed-i-w-trakcie-pandemii-COVID-19.pdf (accessed on 15 March 2021).

89. Bercha, O. The impact of coronavirus on small business in Poland. Sci. Notes Ostroh Acad. Natl. Univ. Econ. Ser. 2020, 19. [CrossRef]

90. Banaszak, A.M. Lack of social security of the workers of gastronomic business in Poland due to the epidemic covid-19. OPUS Uluslararası Toplum Araştırmaları Dergisi 2021, 17, 3185-3198. [CrossRef]

91. Zajkowski, R.; Żukowska, B.A. Family Businesses during the COVID-19 Crisis-Evidence from Poland. Ann. Univ. Mariae Curie-Skłodowska Sectio H Oeconomia 2020, 3, 101-106. [CrossRef]

92. Gazeta Wyborcza. “Tarcz" Nie Obejmie Wielu Firm Obsługujących Turystów Zagranicznych. Odbije SIE to na budżecie Krakowa, September 2020. Available online: https:/ / krakow.wyborcza.pl/krakow /7,44425,26334161,turystyczna-tarcza-nie-dla-krakowa. html. (accessed on 15 March 2021).

93. Wasza Turystyka [Internet Tourism Information Portal]. Sejm Uchwalił Ustawę o Bonie Turystycznym, June 2020. Available online: https:/ / www.waszaturystyka.pl/sejm-uchwalil-ustawe-o-bonie-turystycznym/ (accessed on 15 March 2021).

94. Ministry of Economic Development, Labour and Technology. [Official Website]. Tourist Voucher. Available online: https: //www.gov.pl/web / development-labour-technology/tourist-voucher (accessed on 15 March 2021). 
95. Wirtualna Polska [Internet Information Portal]. Bon Turystyczny. Problemy z Aktywacją i Skargi, September 2020. Available online: https:/ / finanse.wp.pl/bon-turystyczny-problemy-z-aktywacja-i-skargi-6551361602878272a (accessed on 15 March 2021).

96. Bankier.pl [Internet Information Portal]. Trzeba Powiązać Wsparcie dla Turystyki ze Spadkiem Obrotów, a nie z Kodem PKD, December 2020. Available online: https:/ / www.bankier.pl/wiadomosc/KO-Trzeba-powiazac-wsparcie-dla-turystyki-zespadkiem-obrotow-a-nie-z-kodem-PKD-8021731.html (accessed on 15 March 2021).

97. Zarządzenie nr 7. Ministra Rozwoju, Pracy i Technologii z dnia 26 stycznia 2021 r. w sprawie utworzenia Rady Ekspertów do spraw Turystyki [Ordinance No. 7 of the Minister of Development, Labor and Technology of 26 January 2021 on the establishment of the Tourism Experts Council], Dz.Urz.MRPiT.2021.8. Available online: https://sip.lex.pl/akty-prawne/dzienniki-resortowe/ utworzenie-rady-ekspertow-do-spraw-turystyki-35852436 (accessed on 15 April 2020).

98. Pandemic and Tourism in Małopolska till 2021, Interview with Grzegorz Biedron (CEO, DMO Małopolska), 10 June 2020, Economic Forum. Available online: https:/ / www.forum-ekonomiczne.pl/pandemic-and-tourism-in-malopolska-till-2021/? lang=en (accessed on 15 May 2021).

99. Malopolska. [Malopolska Voivodiship Official Website]. Małopolska Turystyka Kontra Koronawirus, March 2021. Available online: https: / / www.malopolska.pl/aktualnosci/turystyka/walka-z-koronawirusem-a-malopolska-turystyka (accessed on 15 March 2021).

100. Malopolska. [Malopolska Voivodiship Official Website]. Certyfikat "Małopolska-Bezpieczna Turystyka", August, 2020. Available online: https://www.malopolska.pl/aktualnosci/turystyka/certyfikat-malopolska-bezpieczna-turystyka (accessed on 15 March 2021).

101. Krakow Nasze Miasto [Local Information Portal]. Zamieszanie Wokół Tarczy Antykryzysowej, September 2020. Available online: https:/ / krakow.naszemiasto.pl/zamieszanie-wokol-tarczy-antykryzysowej-przedsiebiorcy/ar/c3-7878429 (accessed on 15 March 2021).

102. Urząd Miasta Krakowa [City of Krakow], Pauza Program dla Przedsiębiorców [Program Pauza-Support for Business in COVID-19 time], Zarządzenie Prezydenta UMK.; March 2020. Available online: https:/ /www.bip.krakow.pl/?dok_id=124203 (accessed on 15 March 2021).

103. Krakow Nasze Miasto [Local Information Portal]. Przedsiębiorcy Mogą Wysyłać Wnioski o Obniżenie Stawek Czynszowych w Lokalach Miejskich, February 2021. Available online: https: / / krakow.naszemiasto.pl/krakow-przedsiebiorcy-moga-wysylacwnioski-o-obnizenie/ar/c3-8124859 (accessed on 15 March 2021).

104. Badz Turysta w Swoim Miescie [Official Website]. Available online: badzturysta.pl/ (accessed on 15 March 2021).

105. The \#zwiedzajKrakow [\#visitKrakow] Program Regulations Implemented as Part of the Krakow Undiscovered Promotional Campaign. Available online: http:/ / media.krakow.travel/get/47312 (accessed on 1 April 2021).

106. Information Brochure Staying Safe in Krakow. Available online: https: / $/$ www.google $\cdot \operatorname{com} /$ url sa $=t \& r c t=j \& q=\& e s r c=s \&$ source=web\&cd=\&ved=2ahUKEwjnv7iEuI_xAhXByYUKHecBDH0QFjAAegQIBBAD\&url=https\%3A\%2F\%2Fwww.krakow. pl\%2Fzalacznik\%2F334202\&usg=AOvVaw3qEhU8DounMhyimruarwQU (accessed on 15 March 2021).

107. Kraków‘Culture [Official Website]. Available online: https:// krakowculture.pl/ (accessed on 30 May 2021).

108. Murzyn-Kupisz, M.; Hołuj, D. Museums and Coping with Overtourism. Sustainability 2020, 12, 2054. [CrossRef]

109. Krakow Network Protocol. 2021. Available online: https://krakownetwork.pl/wp-content/uploads/2021/04/Krakow_ Network_Protocol_EN.pdf (accessed on 15 March 2021).

110. Kaohsiung Protocol. Strategic Recovery Framework for the Global Events Industry, ICCA. Available online: https://www. iccaworld.org/cnt/docs/ICCA\%20Kaohsiung\%20Protocol.pdfttps://www.iccaworld.org/newsarchives/archivedetails.cfm? id=4090333 (accessed on 15 March 2021).

111. Szromek, A.R.; Kruczek, Z.; Walas, B. Stakeholders' attitudes towards tools for sustainable tourism in historical cities. Tour. Recreat. Res. 2021. [CrossRef]

112. Nientied, P.; Toto, R. Learning from overtourism: New tourism policy for the city of Rotterdam. Urban Res. Pract. 2020, 13, 557-565. [CrossRef]

113. Brouder, P. Reset redux: Possible evolutionary pathways towards the transformation of tourism in a COVID-19 world. Tour Geogr. 2020, 22, 484-490. [CrossRef]

114. OECD. Policy Responses to Coronavirus (COVID-19) Cities Policy Responses, July 2020. Available online: http: / www.oecd.org/ coronavirus / policy-responses / cities-policy-responses-fd1053ff / (accessed on 20 December 2020).

115. Kowalczyk-Anioł, J. Hipertrofia Turystyki Miejskiej-Geneza i Istota Zjawiska. Konwersatorium Wiedzy Mieście 2019, 32, 7-18. Available online: http:/ / hdl.handle.net/11089/35068 (accessed on 20 December 2020). [CrossRef]

116. Rutynskyi, M.; Kushniruk, H. The impact of quarantine due to COVID-19 pandemic on the tourism industry in Lviv (Ukraine). Problem. Perspect. Manag. 2020, 18, 194. [CrossRef]

117. Agostino, D.; Arnaboldi, M.; Lampis, A. Italian state museums during the COVID-19 crisis: From onsite closure to online openness. Mus. Manag. Curatorship 2020, 35, 362-372. [CrossRef]

118. Garcia, B.M. Integrating culture in post-crisis urban recovery: Reflections on the power of cultural heritage to deal with crisis. Int. J. Disaster Risk Reduct 2021, 60, 102277. Available online: http:/ / hdl.handle.net/10986/35681 (accessed on 15 March 2021). [CrossRef] 
119. European Commission. Communication from the Commission to the European Parliament, the European Council and the Council. A Common Path to Safe and Sustained Re-opening, Brussels 17.3.2021, COM 129 final. Available online: https: / / ec.europa.eu/info/sites/default/files/communication-safe-sustained-reopening_en.pdf (accessed on 15 May 2021).

120. Richards, G. Tourists in their own city-Considering the growth of a phenomenon. Tour. Today 2016, 16, 8-16. Available online: https:/ / www.academia.edu/34925642/Tourists_in_their_own_city_published_version (accessed on 15 May 2021).

121. Richards, G. Rethinking Cultural Tourism; Edward Elgar Publishing Ltd.: Cheltenham, UK, 2021; ISBN 978-1 78990-543-4.

122. Duxbury, N. Cultural sustainability, tourism, and development: Articulating connections. In Cultural Sustainability, Tourism and Development. (Re)articulation in Tourism Context; Duxbury, N., Ed.; Routledge: London, UK, 2021; pp. 1-18, ISBN 978-036-720-175-3.

123. Wróblewski, S.; Patterson, I.; Nartov, P. Institutional advancement as a reaction to the COVID-19 pandemic in the tourim city of Samarkand, Uzbekistan. J. Tour. Manag. Res. 2021, 8, 88-100. [CrossRef]

124. Sautet, F. The Role of Institutions in Entrepreneurship: Implications for Development Policy. Bus. Public Adm. Stud. 2020, 14, 29-35. Available online: https://www.bpastudies.org/index.php/bpastudies/article/view/242 (accessed on 15 March 2021). 